The Agriculturists 18(1): 10-17 (2020) ISSN 2304-7321 (Online), ISSN 1729-5211 (Print)

A Scientific Journal of Krishi Foundation

Indexed Journal

DOI: https://doi.org/10.3329/agric.v18i1.49454

\title{
Germination and Seedling Leaf Chlorophyll Content of Wheat (Triticum aestivum L.) Grown under Industrial Wastewater Condition
}

\author{
S. K. Pramanik* and S. Sikder \\ Department of Crop Physiology and Ecology, Hajee Mohammad Danesh Science and Technology \\ University, Dinajpur 5200, Bangladesh \\ *Corresponding author and Email: pramaniksk100@gmail.com
}

Received: 11 April $2020 \quad$ Accepted: 25 June 2020

\begin{abstract}
The tobacco industry is one of the biggest industries in the world generates and disposes large quantities of wastewater in the environment which may be toxic to the plant, animal, public health as well as environment. Therefore, an experiment was conducted during November, 2019 at Crop Physiology and Ecology Laboratory, Hajee Mohammad Danesh Science and Technology University, Dinajpur, Bangladesh to observe the effects of tobacco industry wastewater on germination, early seedling growth and seedling leaf chlorophyll content of wheat (Triticum aestivum L.). Three wheat genotypes (BARI Gom 28, BARI Gom 29 and BAW 1177) and two growing conditions (normal tap water and tobacco industry wastewater) were assigned in a completely randomized design with three replications in germination test. Results showed that germination characteristics, seedling growth and chlorophyll content in leaf of seedling significantly influenced by wheat genotype, growing condition and their interaction. Irrigation with tobacco industry wastewater lowered the germination percentage, rate of germination, co-efficient of germination and vigor index. However, seedlings irrigated with tobacco industry wastewater produced longer shoot and root as compared to seedlings irrigated with tap water. Similarly, tobacco industry wastewater increased the shoot and root dry weight but reduced the chlorophyll content in leaf of seedling. Among the three wheat genotypes, BAW 1177 performed better under both tap water and wastewater conditions regarding germination, early growth and chlorophyll content in leaf of seedling.
\end{abstract}

Keywords: Wheat, tobacco-wastewater, germination, growth, chlorophyll

\section{Introduction}

The tobacco industry is one of the biggest industries in the world. Current techniques of manufacturing tobacco products are quite different from ancient methods as it includes many additive chemicals to provide better taste (Gönen, 2005). However, large quantities of wastewater are generated in tobacco industries during processing and cigarette-making which may be toxic to the environment and public health (Alabi et al., 2014). Tobacco manufacturing is two-step process where first step is the production of tobacco that does not contribute to contaminate the water. But in second step nicotine, synthetic flavoring agents and residues of pesticides are added to water which make the wastewater (Chidambara and 
Han, 2004). The tobacco industry wastewater contains some toxic contaminants which inhibit the microbial consortium in biological treatment plants. Sources of these toxic contaminants are nicotine, flavoring chemicals containing glycogen and alcohol, absorbable organic halogens and pesticides from tobacco leaves (Sponza, 2002). Overall, the tobacco industry ranked 18th among all industries in total chemical waste production (Novotny et al., 2009). In spite of the large quantities of wastewater generated by the tobacco industry and the potential environmental and public health effect, there is little information in the literature about toxicity of the tobacco industry wastewater on plant growth.

In Bangladesh, wheat is cultivated all over the country, but major area is concentrated in northern part. Wheat is generally grown under rain fed condition during the dry winter months (November to March). During this period, soil moisture content goes below the field capacity which reduces seed germination, delays different metabolic processes and finally reduces the yield of wheat. Therefore, one or two supplementary irrigation(s) is/are required for successful production of wheat in northern Bangladesh.

Water quality for irrigation is an utmost important criterion for successful crop production as it contains different ions in varying concentrations. If low quality of water is used for irrigation, toxic elements may hamper growth, development and yield of a crop and also deteriorates soil properties.

In the northern region of Bangladesh, most of the farmers face acute shortage of irrigation water during dry season. The farmers living near the tobacco industry use tobacco industry wastewater for cultivating wheat without testing of water quality. There seems to be a lack of information about the effects of tobacco industry wastewater on crop production. It is hypothesized that toxic chemicals from tobacco industry origin wastewater could interfere in germination, growth and development of wheat.
Therefore, the experiment was conducted to assess the effects of tobacco industry wastewater on germination, early seedling growth and seedling leaf chlorophyll content of wheat genotypes.

\section{Materials and Methods}

\subsection{Location and duration}

The experiment was conducted during November, 2019 at Crop Physiology and Ecology Laboratory, Hajee Mohammad Danesh Science and Technology University, Dinajpur, Bangladesh.

\subsection{Experimental design and treatments}

Laboratory experiment was carried out in a completely randomized design with three replications. Three wheat genotypes (BARI Gom 28, BARI Gom 29 and BAW 1177) were assigned for evaluating germination capacity under tobacco industry wastewater. A control set up was considered using only tap water.

\subsection{Collection of seed and wastewater}

Healthy seeds of three wheat genotypes were collected from Bangladesh Wheat and Maize Research Institute, Nashipur, Dinajpur. The wastewater samples were collected from the drainage system of three tobacco industries (Akij Tobacco Industry Ltd., Abul Khayer Tobacco Industry Ltd., and British American Tobacco Bangladesh Ltd.) situated in Rangpur City. Samples were collected in plastic bottles that had been cleaned with hydrochloric acid (1:1) and then rinsed with tap water followed by rinsing with distilled water. The water samples collected from three industries were mixed thoroughly and considered as $100 \%$ wastewater.

\subsection{Seed placement for germination}

Clean, air dried and sterilized petri-dishes $(11 \mathrm{~cm}$ diameter) were taken for germination test. Twenty-five seeds of each genotype were placed on filter paper sprinkled with respective treatment solution. Before placing, seeds were surface sterilized in $0.1 \%$ mercuric chloride solution for 30 seconds, and then the seeds were 
washed thoroughly with tap water followed by distilled water. The entire set up was then kept in a well ventilated and diffused sunlight mediated room. Each petridish containing the seeds was irrigated with respective treatment solution at 1day interval throughout the experimental period (12 days).

\subsection{Data recorded on germination}

Germination was counted at 24-hours interval and continued up to $5^{\text {th }}$ day. A seed was considered germinated when plumule and radicle came out and larger than $2 \mathrm{~mm}$ long. The percentage of germination was considered at $5^{\text {th }}$ day of placement of seeds. The rate of germination was calculated according to Krishnasamy and Seshu (1990) and co-efficient of germination and vigor index were calculated using the formulae of Copeland (1976).

\subsection{Data recorded on growth attributes}

The length of shoot and root of seedling was recorded by centimeter scale at 12 days after placement. Five seedlings from each petridish were sampled for shoot and root length. Then shoot and root were dried separately at $70^{\circ} \mathrm{C}$ for 72 hours in an electric oven and weight were recorded with an electrical balance. The mean length and dry weight were calculated for each treatment combination.

\subsection{Determination of chlorophyll}

Total chlorophyll content of leaf was determined at 12 days after placement of seeds according to Witham et al. (1986). Total chlorophyll content was determined in the acetone extract $(80 \% \mathrm{v} / \mathrm{v})$ measured in a spectrophotometer at 645 and 663 $\mathrm{nm}$ and the concentration was expressed as $\mathrm{mg}$ chlorophyll $\mathrm{g}^{-1}$ fresh weight by using the following equations-

Total chlorophyll $\left(\mathrm{mg} \mathrm{g}^{-1} \mathrm{FW}\right)=\left[20.2\left(\mathrm{D}_{645}\right)\right.$ $\left.+8.02\left(\mathrm{D}_{663}\right)\right] \times[\mathrm{V} /(1000 \times \mathrm{W})]$

Where, $\mathrm{V}=$ Volume of $80 \%$ aqueous acetone $(\mathrm{ml}), \mathrm{W}=$ Weight of fresh leaf $(\mathrm{g})$

$\mathrm{D}_{645}=$ Absorbance at $645 \mathrm{~nm}$ wavelength and $\mathrm{D}_{663}=$ Absorbance at $663 \mathrm{~nm}$ wavelength

\subsection{Statistical analysis}

The data were analyzed by partitioning the total variance using Statistix 10 program and the means were compared by Tukey's Test.

\section{Results and Discussion}

\subsection{Germination characteristics}

Percentage of germination, germination rate, coefficient of germination and vigor index were significantly influenced by both wheat genotype and growing condition (Table 1). Maximum germination percentage $(86.85 \%)$ and germination rate $(39.87 \%)$ was found in BAW 1177. Other two genotypes showed lower but statistically similar germination percentage and germination rates. Maximum co-efficient of germination (27.37) was also found in BAW 1177 which was statistically similar to that of BARI Gom 28. Vigor index indicated that the genotype BAW 1177 was more vigorous (21.99) than other two genotypes although they were statistically similar to each other. Tobacco industry wastewater inhibited the germination capacity of wheat as indicated by its lower germination percentage $(75.16 \%)$, germination rate $(19.67 \%)$, co-efficient of germination (25.01) and vigor index (16.74) as compared to those parameters $(86.96 \%, 36.89 \%, 27.17$ and 24.33, respectively) under control conditions.

The interaction effect of wheat genotype and growing condition was found significant on germination percentage, germination rate, coefficient of germination and vigor index (Table 2). Under control condition the genotype BAW 1177 showed maximum germination percentage $(91.33 \%)$, germination rate $(51.28 \%)$, coefficient of germination (28.84) and vigor index (25.63). Tobacco industry wastewater negatively affected the germination characteristics of all wheat genotypes but in different magnitudes. Under tobacco industry wastewater, maximum germination percentage $(82.37 \%)$, germination rate $(28.45 \%)$ and vigor index (18.35) were observed in the genotype BAW 1177. While maximum co-efficient of germination (26.36) was observed in genotype BARI Gom 28. 
Table 1. Effect of genotype and tobacco industry wastewater on germination characteristics of wheat

\begin{tabular}{ccccc}
\hline Treatments & Germination $(\%)$ & $\begin{array}{c}\text { Germination } \\
\text { rate }(\%)\end{array}$ & $\begin{array}{c}\text { Co-efficient of } \\
\text { germination }\end{array}$ & $\begin{array}{c}\text { Vigor } \\
\text { index }\end{array}$ \\
\hline Genotypes & $78.28 \mathrm{~b}$ & $22.94 \mathrm{~b}$ & $27.27 \mathrm{a}$ & $20.33 \mathrm{~b}$ \\
BARI Gom 28 & $78.05 \mathrm{~b}$ & $22.04 \mathrm{~b}$ & $23.63 \mathrm{~b}$ & $19.12 \mathrm{~b}$ \\
BARI Gom 29 & $86.85 \mathrm{a}$ & $39.87 \mathrm{a}$ & $27.37 \mathrm{a}$ & $21.99 \mathrm{a}$ \\
BAW 1177 & 0.01 & 0.01 & 0.01 & 0.01 \\
\hline Level of significance & & & & \\
Growing conditions & $86.96 \mathrm{a}$ & $36.89 \mathrm{a}$ & $27.17 \mathrm{a}$ & $24.23 \mathrm{a}$ \\
Control & $75.16 \mathrm{~b}$ & $19.67 \mathrm{~b}$ & $25.01 \mathrm{~b}$ & $16.74 \mathrm{~b}$ \\
Waste water & 0.01 & 0.01 & 0.01 & 0.01 \\
Level of significance & 3.68 & 4.50 & 5.38 & 4.79 \\
CV $(\%)$ & &
\end{tabular}

In a column, means followed by the same letter(s) did not differ significantly at $P \leq 0.05$ level by Tukey.

Table 2. Interaction effect of genotype and tobacco industry wastewater on germination characteristics of wheat

\begin{tabular}{|c|c|c|c|c|c|}
\hline Wheat genotypes & $\begin{array}{l}\text { Growing } \\
\text { conditions }\end{array}$ & $\begin{array}{c}\text { Germination } \\
(\%)\end{array}$ & $\begin{array}{c}\text { Germinatio } \\
\text { n rate }(\%)\end{array}$ & $\begin{array}{l}\text { Co-efficient of } \\
\text { germination }\end{array}$ & $\begin{array}{l}\text { Vigor } \\
\text { index }\end{array}$ \\
\hline \multirow{2}{*}{ BARI Gom 28} & Control & $85.55 \mathrm{ab}$ & $31.54 \mathrm{~b}$ & $28.18 \mathrm{ab}$ & $24.54 \mathrm{ab}$ \\
\hline & Waste water & $71.00 \mathrm{c}$ & $14.33 d$ & $26.36 \mathrm{abc}$ & $16.12 \mathrm{c}$ \\
\hline \multirow{2}{*}{ BARI Gom 29} & Control & $83.99 \mathrm{ab}$ & $27.86 \mathrm{c}$ & $24.49 b c$ & $22.51 b$ \\
\hline & Waste water & $72.11 \mathrm{c}$ & $16.22 \mathrm{~d}$ & $22.77 \mathrm{c}$ & $15.74 \mathrm{c}$ \\
\hline \multirow{2}{*}{ BAW 1177} & Control & $91.33 \mathrm{a}$ & $51.28 \mathrm{a}$ & $28.84 \mathrm{a}$ & $25.63 a$ \\
\hline & Waste water & $82.37 \mathrm{~b}$ & $28.45 b c$ & $25.91 \mathrm{abc}$ & $18.35 \mathrm{c}$ \\
\hline \multirow{2}{*}{\multicolumn{2}{|c|}{$\begin{array}{l}\text { Level of significance } \\
\text { CV }(\%)\end{array}$}} & 0.05 & 0.01 & 0.05 & 0.05 \\
\hline & & 3.68 & 4.50 & 5.38 & 4.79 \\
\hline
\end{tabular}

In a column, means followed by the same letter(s) did not differ significantly at $P \leq 0.05$ level by Tukey.

However, the interaction effect of wheat genotype and growing condition revealed that maximum germination percentage, germination rate, co-efficient of germination and vigor index were found in genotype BAW 1177 under control conditions. It also revealed that minimum germination percentage and germination rate were found in genotype BARI Gom 28, while the minimum co-efficient of germination and vigor index were found in genotype BARI Gom 29 under wastewater condition.

Differential degree of response in speed of germination of wheat genotypes to different growing conditions might be due to genetic variability of the crop. The decline in germination characteristics under wastewater condition is probably due to the chemical fraction which leads to the inhibition of germination (Bhalla, 1973). Suseelamma and Venkataraju (1994) also reported that the inhibition of germination is dependent on the concentration of extract from cigarette tobacco leaf and its entry to growing points of seedlings. Other authors (Mayer and Poljakoff-Mayer, 1963) concluded that released alleochemicals from wastewater probably interferes with the plant growth regulators during germination and inhibits early seedling growth that support our findings. 


\subsection{Early seedling growth}

Wheat genotypes did not differ significantly on shoot length but the root length, shoot dry weight and root dry weight varied significantly due to genotypes (Table 3). Among the three genotypes, BAW 1177 produced the longest root $(10.19 \mathrm{~cm})$ which was statistically at par with root length $(9.84 \mathrm{~cm})$ produced by BARI Gom 29. The genotype BAW 1177 also accumulated maximum shoot dry weight $\left(0.173 \mathrm{mg} \mathrm{plant}^{-1}\right)$ and root dry weight $\left(0.197 \mathrm{mg} \mathrm{plant}^{-1}\right)$, whereas other two genotypes showed statistically identical shoot dry weight and root dry weight. Tobacco industry wastewater increased the length of shoot and root $(8.33 \mathrm{~cm}$ and $11.17 \mathrm{~cm}$, respectively) as well as shoot and root dry weight (0.194 mg plant ${ }^{-1}$ and $0.212 \mathrm{mg} \mathrm{plant}^{-1}$, respectively) as compared to control conditions $\left(6.58 \mathrm{~cm}, 8.95 \mathrm{~cm}, 0.169 \mathrm{mg} \mathrm{plant}^{-1}\right.$ and 0.184 mg plant $^{-1}$, respectively).

The shoot length, root length, shoot dry weight and root dry weight also varied significantly by the interaction effect of wheat genotype and growing condition (Table 4). Under control condition, longest shoot and root $(6.77 \mathrm{~cm}$ and $9.51 \mathrm{~cm}$, respectively) was found in BAW 1177 which was statistically identical with other two genotypes $(6.39 \mathrm{~cm}$ and $8.21 \mathrm{~cm}$ in BARI Gom 28 and $6.57 \mathrm{~cm}$ and $9.12 \mathrm{~cm}$ in BARI Gom 29).

Table 3. Effect of genotype and tobacco industry wastewater on early seedling growth of wheat

\begin{tabular}{|c|c|c|c|c|}
\hline Treatments & $\begin{array}{l}\text { Shoot length } \\
(\mathrm{cm})\end{array}$ & $\begin{array}{l}\text { Root length } \\
(\mathrm{cm})\end{array}$ & $\begin{array}{l}\text { Shoot dry weight } \\
\text { plant }^{-1}(\mathrm{mg})\end{array}$ & $\begin{array}{c}\text { Root dry weight } \\
\text { plant }^{-1}(\mathrm{mg})\end{array}$ \\
\hline \multicolumn{5}{|l|}{ Genotypes } \\
\hline BARI Gom 28 & 6.77 & $9.49 \mathrm{~b}$ & $0.161 b$ & $0.170 \mathrm{~b}$ \\
\hline BARI Gom 29 & 6.49 & 9.84ab & $0.166 b$ & $0.173 b$ \\
\hline BAW 1177 & 6.86 & $10.19 \mathrm{a}$ & $0.173 \mathrm{a}$ & $0.197 \mathrm{a}$ \\
\hline Level of significance & NS & 0.05 & 0.01 & 0.01 \\
\hline \multicolumn{5}{|l|}{ Growing conditions } \\
\hline Control & $6.58 b$ & $8.95 b$ & $0.169 b$ & $0.184 b$ \\
\hline Waste water & $8.33 \mathrm{a}$ & $11.17 \mathrm{a}$ & $0.194 \mathrm{a}$ & $0.212 \mathrm{a}$ \\
\hline Level of significance & 0.01 & 0.01 & 0.01 & 0.01 \\
\hline $\mathrm{CV}(\%)$ & 5.48 & 5.38 & 5.05 & 2.34 \\
\hline
\end{tabular}

In a column, means followed by the same letter(s) did not differ significantly at $P \leq 0.05$ level by Tukey.

Table 4. Interaction effect of genotype and tobacco industry wastewater on early seedling growth of wheat

\begin{tabular}{|c|c|c|c|c|c|}
\hline $\begin{array}{c}\text { Wheat } \\
\text { Genotypes }\end{array}$ & $\begin{array}{l}\text { Growing } \\
\text { conditions }\end{array}$ & $\begin{array}{l}\text { Shoot length } \\
\text { (cm) }\end{array}$ & $\begin{array}{l}\text { Root length } \\
\text { (cm) }\end{array}$ & $\begin{array}{l}\text { Shoot dry weight } \\
\text { plant- }{ }^{-1}(\mathrm{mg})\end{array}$ & $\begin{array}{l}\text { Root dry weight } \\
\text { plant- }{ }^{1}(\mathrm{mg})\end{array}$ \\
\hline \multirow{2}{*}{ BARI Gom 28} & Control & $6.39 b$ & $8.21 \mathrm{c}$ & $0.163 \mathrm{c}$ & $0.172 \mathrm{c}$ \\
\hline & Waste water & 7.64ab & $9.66 \mathrm{~b}$ & $0.187 \mathrm{ab}$ & $0.190 \mathrm{~b}$ \\
\hline \multirow{2}{*}{ BARI Gom 29} & Control & $6.57 b$ & $9.12 b c$ & $0.169 \mathrm{c}$ & $0.175 \mathrm{c}$ \\
\hline & Waste water & $8.73 a$ & $11.68 \mathrm{a}$ & $0.196 \mathrm{a}$ & $0.205 b$ \\
\hline \multirow{2}{*}{ BAW 1177} & Control & $6.77 b$ & $9.51 b$ & $0.175 b c$ & $0.205 b$ \\
\hline & Waste water & $8.59 \mathrm{a}$ & $12.16 \mathrm{a}$ & $0.199 \mathrm{a}$ & $0.241 \mathrm{a}$ \\
\hline \multicolumn{2}{|c|}{ Level of significance } & 0.05 & 0.05 & 0.05 & 0.01 \\
\hline \multicolumn{2}{|c|}{$\mathrm{CV}(\%)$} & 5.48 & 5.38 & 5.05 & 2.34 \\
\hline
\end{tabular}

In a column, means followed by the same letter(s) did not differ significantly at $P \leq 0.05$ level by Tukey. 
Maximum shoot dry weight $\left(0.175 \mathrm{mg}\right.$ plant $\left.^{-1}\right)$ was observed in BAW 1177 although it was statistically similar to other two genotypes (0.163 $\mathrm{mg} \mathrm{plant}^{-1}$ in BARI Gom 28 and $0.169 \mathrm{mg}$ plant $^{-1}$ in BARI Gom 29). Root dry weight (0.205 $\mathrm{mg}$ plant $^{-1}$ ) was also maximum in BAW 1177 , whereas other two genotypes produced lower but statistically similar root dry weight (0.172 mg plant ${ }^{-1}$ in BARI Gom 28 and $0.175 \mathrm{mg}$ plant $^{-1}$ in BARI Gom 29). Tobacco industry wastewater significantly increased the early growth of wheat seedlings in different magnitudes compared to control condition. Under tobacco industry wastewater, maximum shoot length $(8.73 \mathrm{~cm})$ was found in BARI Gom 28 , while maximum root length $(12.16 \mathrm{~cm})$, shoot dry weight $\left(0.199 \mathrm{mg}\right.$ plant $\left.^{-1}\right)$ and root dry weight $\left(0.241 \mathrm{mg} \mathrm{plant}^{-1}\right)$ were found in BAW 1177.

However, the interaction effect of wheat genotype and growing condition showed that maximum shoot length was found in genotype BARI Gom 29 under wastewater condition which was statistically similar to shoot length produced by genotype BAW 1177 under similar growing condition. Maximum root length and shoot dry weight were observed in genotype BAW 1177 under wastewater conditions which were statistically identical to that of BARI Gom 29 under wastewater condition. Maximum root dry weight was also found in BAW 1177 under wastewater condition. Among the different treatment combinations BARI Gom 28 produced minimum shoot length (statistically identical to other genotypes), root length (followed by BARI Gom 29), shoot dry weight (statistically identical to other genotypes) and root dry weight under control conditions.

The increasing in the shoot and root length of wheat seedlings under wastewater treatment might be due to presence of organic matter in tobacco industry wastewater which resulted in more dry matter accumulation in shoot and root. Another reason might be that the wastewater may activate some growth activating enzyme during germination, which in turn increase the amount of the hydrolyzates (glucose and amino acids) which are required for growth of embryo axes.

The results of the present study are in a line with the results observed by Hossain et al. (2018). They observed that irrigation with tobacco industry wastewater increased the shoot and root length in cucumber, radish and long yard bean seedlings under laboratory condition. Mojiri et al. (2013) also found increase in shoot and root length of Lepidium sativum when irrigated with wastewater that consistent with our findings.

\subsection{Total chlorophyll content}

Interaction effect of wheat genotype and growing condition revealed that among different treatment combinations maximum leaf chlorophyll content $\left(1.34 \mathrm{mg} \mathrm{g}^{-1} \mathrm{FW}\right)$ was found in BAW 1177 although it was statistically similar to other two genotypes under control condition, whereas minimum leaf chlorophyll content $\left(0.56 \mathrm{mg} \mathrm{g}^{-1} \mathrm{FW}\right)$ was found in BARI Gom 29 under wastewater condition (Table 5). Tobacco industry wastewater caused reduction of seedling leaf chlorophyll content by $46.61 \%$ in BARI Gom 28, 53.72\% in BARI Gom 29 and $36.57 \%$ in BAW 1177 genotype. However, under tobacco industry wastewater, again maximum chlorophyll content $\left(0.85 \mathrm{mg} \mathrm{g}^{-1} \mathrm{FW}\right)$ was found in the BAW 1177 genotype.

Jianhua et al. (2012) concluded that the reduction of leaf chlorophyll pigment is due to presence of Benzoic acid and Phthalate which released from the smoke and tobacco leaf as an allelochemicals. Another possibility is that the allelochemicals may partially block the biosynthetic pathway of chlorophyll, or stimulate the degradative pathway of chlorophyll, or both, leading to a reduction of chlorophyll accumulation (Gibson and Liebman, 2003).

Result of present study also supported by Mondal et al. (2014) who mentioned that the cigarette origin tobacco leaf extract reduced the chlorophyll content in leaf of Bengal gram. 
Table 5. Interaction effect of genotype and tobacco industry wastewater on seedling leaf chlorophyll content of wheat

\begin{tabular}{cccc}
\hline Wheat Genotypes & Growing conditions & $\begin{array}{c}\text { Total chlorophyll } \\
\text { content }\left(\mathrm{mg} \mathrm{g}^{-1} \mathrm{FW}\right)\end{array}$ & $\begin{array}{c}\text { \% reduction over } \\
\text { control }\end{array}$ \\
\hline \multirow{2}{*}{ BARI Gom 28 } & Control & $1.18 \mathrm{a}$ & 46.61 \\
& Waste water & $0.63 \mathrm{c}$ & 53.72 \\
BARI Gom 29 & Control & $1.21 \mathrm{a}$ & \multirow{2}{*}{36.57} \\
& Waste water & $0.56 \mathrm{c}$ & \\
BAW 1177 & Control & $1.34 \mathrm{a}$ & \\
\multicolumn{2}{c}{ Level of significance } & $0.85 \mathrm{~b}$ & \\
\multicolumn{2}{c}{ CV $(\%)$} & 0.05 & \\
\hline
\end{tabular}

In a column, means followed by the same letter(s) did not differ significantly at $P \leq 0.05$ level by Tukey.

\section{Conclusions}

From the results of this study, it can be concluded that tobacco industry wastewater reduced the speed of germination and chlorophyll content in seedling leaf but accelerated the early seedling growth of wheat. Therefore, the tobacco industry wastewater should be tested for its suitability for irrigation and treated to remove the pollutants before using it for irrigation purpose. Among the three wheat genotypes, BAW 1177 performed better under both tap water and wastewater conditions in relation to germination, early seedling growth and maintaining maximum chlorophyll content in seedling leaf.

\section{References}

Alabi OA., Evi OW., Precious Y., Moruf L., Adekunle AB. 2014. Tobacco industry wastewater-induced genotoxicity in mice using the bone marrow micronucleus and sperm morphology assays. Cytologia, 79(2):215-225.

Bhalla PR., Whitaker TW., Sabharwal PS. 1973. Effect of water soluble tobacco smoke extracts from filter and non-filter cigarettes on seed germination of onion and tomato. Environmental Pollution, 5:231-236.
Chidambara RCB., Han LQ. 2004. Advanced oxidation processes for wastewater treatment: Optimization of UV/ $\mathrm{H}_{2} \mathrm{O}_{2}$ process through a statistical technique. Chemical Engineering Science, 60:53055311.

Copeland LO. 1976. Principles of seed science and technology, Burgess Publication Company, Minneapolis, Minnesota, 164$165 \mathrm{pp}$.

Gibson L.R., Liebman M. 2003. A laboratory exercise for teaching plant interference and relative growth rate concepts. Weed Technology, 17:394-402.

Gönen Ç. 2005. Treatment of tobacco industry wastewaters by advanced oxidation processes. MS thesis, Graduate School of Natural and Applied Sciences, Dokuz Eylül University, I zmir. pp. 1-78.

Hossain MS., Islam MJ., Sarker BC., Pramanik SK., Khatun R., Zahan MN. 2018. Suitability assessment of wastewater of three tobacco industries for irrigation and germination of some vegetable seeds. International Journal of Science and Business, 2(3):459-479.

Jianhua YI., Zhihong J., Qi L., Huzhen LV., Hong S. 2012. Allelopathic effects of decaying tobacco leaves on tobacco 
seedlings. Allelopathic Journal, 29(1):5162 .

Krishnasamay V., Shehu DV. 1990. Germination after accelerated aging and associated characters in rice varieties. Seed Science and Technology, 18:353-359.

Mayer AM., Poljakoff-Mayber A. 1963. The germination of seeds. Macmillan, New York, NY, 244 p.

Mojiri A., Aziz HA., Aziz SQ., Gholami A., Aboutorab M. 2013. Impact of urban wastewater on soil properties and Lepidium sativum in an arid region. International Journal of Scientific Research in Environmental Sciences, 1(1):1-9.

Mondal NK., Dey U., Khatun S., Das K., Das CR. 2014. Toxic effect of cigarette origin tobacco leaf (Nicotiana tabaccum L.) and cigarette smoke extract on germination and bio-chemical changes of bengal gram
(Cicer arietinum L.). Journal of Stress Physiology and Biochemistry, 10(1):135144.

Novotny TE., Lum K., Smith E. 2009. Cigarettes butts and the case for an environmental policy on hazardous cigarette waste. International Journal of Environmental Research and Public Health, 6:16911705.

Sponza DT. 2002. Toxicity studies in a tobacco industry biological treatment plant. Water, Air and Soil Pollution, 134:137-164.

Suseelamma M., Venkataraju RR. 1994. Effect of Digera muricata (L.) Mart. extracts on the germination and seedling growth of groundnut. Allelopathy Journal, 1:53-57.

Witham H., Blades DF., Devin RH. 1986. Exercise in plant physiology, $2^{\text {nd }}$ edn., PWS Publishers, Boston, USA, 128-131 pp. 